\title{
Explicit Instruction of Scientific Argumentation in Practical Work: A Feasibility Study
}

\author{
Irene Lue Leh Ping, Lilia Halim*, Kamisah Osman \\ Faculty of Education, Universiti Kebangsaan Malaysia, Bangi, Malaysia \\ Email: *lilia@ukm.edu.my
}

How to cite this paper: Ping, I. L. L., Halim, L., \& Osman, K. (2019). Explicit Instruction of Scientific Argumentation in Practical Work: A Feasibility Study. Creative Education, 10, 1205-1229. https://doi.org/10.4236/ce.2019.106091

Received: May 31, 2019

Accepted: June 24, 2019

Published: June 27, 2019

Copyright $\odot 2019$ by author(s) and Scientific Research Publishing Inc. This work is licensed under the Creative Commons Attribution International License (CC BY 4.0).

http://creativecommons.org/licenses/by/4.0/

\section{(c) (i) Open Access}

\begin{abstract}
Mastery regarding argumentation in science among high school biology students remains elusive. This study argues that argumentation can be explicitly taught and acquired through an explicit instruction revolving around argumentation. A teaching and learning module named as the LAB-MADI Module was developed to provide secondary biology students an environment to practice and acquire argumentation skills from reasoning based on evidence through practical work. An initial draft of the LAB-MADI Module for laboratory investigation was pilot studied in one of the schools with a group of twenty-two $(\mathrm{n}=22)$ Grade 10 students (aged 16 years) from a pure science class taking biology as an examination subject. The results of the pilot study showed that the activities are able to improve students' argumentation skills.
\end{abstract}

\section{Keywords}

Argument-Driven Inquiry, Argumentation, Practical Work, Biology, Scientific Inquiry

\section{Introduction}

Scientific knowledge is based on observation and evidence and knowledge is constantly changing as scientists develop theories that attempt to explain natural phenomena through observation and experimentation. Scientists participate in argumentation to formulate and improve scientific knowledge (Nussbaum \& Sinatra, 2003). Science curricula are primarily framed by scientists and their dominant requirement is the need to prepare new scientists for the next generation (Reiss, Millar, \& Osborne, 1999). Argumentation is a genesis of discourse vital to the habits used by members of scientific research to develop and to have the same opinion about science knowledge. It is necessary to develop such a discourse in school science so that students would be able to mirror the habits of 
scientists.

Argumentation in science teaching involves justification of evidence and this requires the usage of science process skills (Gultepe \& Kilic, 2015). Similarly, the practice of argumentation could indirectly strengthen the mastery of science process skills (Demircioglu \& Ucar, 2015; Enderle, Grooms, \& Sampson, 2013; Enderle, Grooms, \& Williams, 2012; Gultepe \& Kilic, 2015; Sampson et al., 2012; Sampson \& Walker, 2012). For students to be able to understand the process of science and its application, the explicit teaching of the justification of evidence in investigation should therefore be provided during practical work (Driver et al., 2000; Osborne, 2015; Osborne et al., 2013; Sampson et al., 2011). Explicit argumentation in practical work requires students to apply science process skills which involve a systematic process of tabulating and analysing data to produce valid evidences that can support decision making when solving the problems in practical work.

There is a need to provide students with opportunities to engage in argumentation in school science to develop students' capacity to collaborate and to teach them how to learn (Hofstein \& Kind, 2012; Osborne, 2012). Scientific argumentation is a new rationale for practical work (Hofstein \& Kind, 2012; Osborne, 2015; Sampson et al., 2011). The exposure of students to the skills of argumentation is still lacking within the context of practical work (Driver et al., 2000; Hofstein \& Kind, 2012; Osborne, 2013, 2015; Sampson \& Clark, 2009). Teachers of science need exemplars of materials and strategies that can be used to develop argumentation with their students (Osborne, 2012). Therefore, calls have been made for science education researchers to engage with practical work and to further develop new teaching strategies for practical work.

\section{Literature Review}

Educational standards increasingly emphasize argumentation skills as goals to science programmes' success in developing students' understanding of both scientific concepts and of how science and scientists work. However, schools mostly fail to develop argumentation skills in students (Driver, Newton, \& Osborne, 2000; Duschl \& Osborne, 2002). This is because students have limited opportunities to learn how to engage in productive scientific argumentation (Newton \& Driver, 1999; Osborne, 2010; Simon, Erduran, \& Osborne, 2006). Without argumentation process, students seem unable to appreciate science concepts and lack the opportunity to practice the ways used by scientists to justify or refute their claim. Therefore, students need more opportunities to learn how to make sense of arguments and correct the misconceptions as well as develop knowledge explicitly.

Learning science effectively through the explicit instruction of scientific argument is often neglected (Foong \& Daniel, 2013; Hasnunidah et al., 2015; Heng \& Surif, 2013a, 2013b; Osborne, 2015) including in practical work (Driver et al., 2000; Hasnunidah et al., 2015; Jiménez-Aleixandre et al., 2000; Kim \& Song, 
2006) when there is overemphasis in the curricula, textbooks, and among teachers on what students know at the expense of how students know (Osborne, 2010). Science learning is often executed in the form of students passively accepting information from the teacher, copying notes, doing drill and practice and "cookbook style" practical activities (Peen \& Arshad, 2013). Such teaching and learning process does not promote students' potential (Akarsu et al., 2013). Most science students have adopted learning approaches or strategies that emphasised rote learning and memorisation (Watters \& Watters, 2007). Science students often experience scientific knowledge as a set of unequivocal and uncontested science facts (Osborne, 2010). Clearly, students would not fully understand the scientific knowledge taught if they are not given the opportunity to experience constructing and evaluating scientific argumentation themselves.

In designing the science teaching processes as well as science inquiry, efforts have continued to cultivate students' habits of constructing and communicating argumentation. However, many science teachers are unsure of how to design lessons that would engage students in inquiry in a way that would improve students' understanding of important concepts and practices in science including in biology (Sampson \& Gleim, 2009; Nur et al., 2018). It is not enough for teachers to teach science as a process of inquiry without giving their students the opportunity to engage in argumentation (Clark \& Sampson, 2007; Driver et al., 2000). This is because argumentation is one of the most important processes of scientific inquiry (Demircioglu \& Ucar, 2015; Sampson, Grooms, \& Walker, 2011). In order to help students understand the science phenomenon, constructing argumentation is a must as a guide for engaging in the inquiry process and as a foundation for the design of inquiry-based science instruction.

Practical work would always have a key role in teaching of science inquiry and it is often claimed that it leads to better learning of scientific concepts and phenomena. In relation to the phenomena of diffusion and osmosis, studies however have found that students often perform practical work involving the phenomena without really understanding the underlying principles (Hasni, Roy, \& Dumais, 2016; Friedler, Amir, \& Tamir, 1987). Furthermore, high school students' mastery regarding the mechanisms of diffusion and osmosis remains difficult to achieve (Hasni et al., 2016; Fisher, Williams, \& Lineback, 2011; Lee \& Daniel, 2012). The challenge is to find ways to make practical work a great deal more effective as a teaching and learning strategy than it often is at present (Millar \& Abrahams, 2009; Osborne, 2015; Tekkaya, 2003; Wei, Chen, \& Chen, 2018) and to eliminate or prevent misconceptions to promote meaningful learning of scientific concepts (Cengiz \& Ayvaci, 2017).

Empirical research over the last two decades has examined ways to promote argumentation in science classrooms and to support students as they learn how to engage in argumentation. Opportunities could be provided through the development of new pedagogical practices (Berland \& Hammer, 2012; Osborne, Erduran, \& Simon, 2004), technology-enhanced learning environments (Clark \& Sampson, 2007; Clark \& Sampson, 2008; Sandoval \& Reiser, 2004), innovative 
argumentation curriculum (McNeill, 2009) and laboratory environment (Çetİn, Metİn, \& Kaya, 2016; Sampson \& Gleim, 2009; Sampson, Grooms, \& Walker, 2009, 2011; Walker, Sampson, \& Zimmerman, 2011). These updated pedagogical practices could be used by teachers as a way to integrate argumentation into the teaching and learning of science.

Studies have shown inconsistent results in the development of argumentation skills of students who are engaged in scientific inquiry activities. Quasi-experimental study by Osborne et al. (2004) where argumentation activities were implemented over a nine-period class schedule showed the change of the quality of student argumentation was not significant. Watson, Swain and McRobbie (2004) in their study found that the quantity and quality of arguments in scientific inquiry among students were also low. These however are contrary to the research findings of Kim and Song (2006); they investigated the arguments made by students engaged in activities of scientific inquiry and found that the students showed improvements in their argumentation process. Becker (2014) in his study found that students' ability in constructing written scientific explanations and arguments and perception of biology as a discipline of science improved but rejected the hypothesis that explicit instruction in scientific explanation and argumentation can improve students' scientific content knowledge and ability to write formal written laboratory report. Thus, the ways in which students can be best supported in laboratory environment remain elusive, and is a challenge for science teachers.

Although argumentation has been emphasized as a core competence of science students, Malaysian teachers are slow to implement the recommended instructional innovations; it appears that Malaysia teachers are not convinced that these approaches have the potential to promote science knowledge as well as other important outcomes. The teaching and learning of science in Malaysia still focuses on teacher-oriented activities and does not expose students to argumentative tasks (Heng \& Surif, 2013a; Heng, Surif, \& Seng, 2014, 2015b). Moreover, the emphasis on high-stakes examinations (Abdullah \& Francis Peters, 2015; Heng, Surif, \& Seng, 2015a; Peen \& Arshad, 2013; Peen \& Arshad, 2014) reinforces the current practice of teaching of science in Malaysia. Hence, students need to be explicitly taught the elements of scientific argumentation and be involved in group-based argumentation sessions to justify their claim with evidence after the practical work sessions. During the argumentation sessions, students would express ideas, provide evaluation, discuss and further revise their ideas collaboratively. Through the development of argumentation skills, students are able to practice critical thinking, communicate effectively, innovate, and solve problems through negotiation and collaboration. All these skills are essential to prepare students for the $21^{\text {st }}$ century workforce.

Research on promoting skills of argumentation in the Malaysian context is relatively new. One particular study is by Foong and Daniel (2013) that introduced skills of argumentation through socio-scientific issues for Form Two stu- 
dents in the Confucian learning environment. The findings from the study showed that the Confucian students were weak in constructing rebuttal in their argument. The method of constructing argumentation through discussion of socio-scientific issues is a new approach in science teaching in Malaysia. Conversely, as argued in the beginning, another method in developing a more suitable approach to scientific inquiry in the context of science teaching to Malaysian secondary school is inquiry through the conduct of practical work. Hence, the formation of argumentation skills through practical-based inquiry activities are the focus of this study.

\section{Purpose of Study}

The objective of this feasibility study is to investigate the feasibility of the instructions and activities in the LAB-MADI module for students and teachers from the perspective of students and teachers. The following are the research questions of this study:

1) What are the effects of the LAB-MADI module on the students' argumentation skills?

2) What is the students' perspective on the feasibility of the LAB-MADI module?

3) What is the teacher's perspective on the feasibility of the LAB-MADI module for Grade 10 students?

\section{Methodology}

\subsection{Research Design}

In this feasibility study, quasi experimental approach with one group treatment design was adopted. Twenty-two students $(n=22)$, from a rural school were divided into six groups and responded to pre-test prior to using the LAB-MADI Module. Two topics from the Biology subject taught at secondary level- "Movement of Substances Across Plasma Membrane" and "Chemical Composition of the Cells were the biology content in the LAB-MADI Module.

The aim of this study, LAB-MADI was to examine whether the teachers could carry out and manage the activities, in the LAB-MADI module, in the absence of coaching by the researcher. The formative evaluation technique was used and this technique ensures that the instruction, regardless of the presentation mode, will be properly implemented and managed as intended by the designer of the module (Dick, Carey, \& Carey, 2015). Furthermore, this study enables one to determine the feasibility of the specific teaching and learning strategies from the students' perspectives. There is a necessity to gather data from the perspective of the students of the target population on the usage and effectiveness of the materials as the information gathered from the students can be used to help make the materials even more effective (Dick et al., 2015). Data from this study was used to revise the instructions and activities in the LAB-MADI module to make it more effective and efficient. 


\subsection{Population and Sample}

The population of study comprised Grade 10 science students taking Biology subject in public secondary schools in Sarawak, one of the states of Malaysia. Students attending public secondary schools in one of the divisions in Sarawak made up the accessible population. Hence, one public school was randomly selected out of twelve secondary schools in the division S.For the consideration on the ethics of educational research, written permission was obtained from each students' parent or guardian after the approval from the Ministry of Education, school principal and classroom teacher.

The LAB-MADI Module pilot study was conducted on a teacher and 22 students in the selected secondary school which would not be involved in the actual study; however, the students have the same capability (in terms of age and maturity) as the students proposed for the actual study. This pilot study would also help the researcher in collecting data and identifying the potential weaknesses that could crop up at the time of collecting the actual data. In terms of demographics, the students enrolled in this pilot study were made up of 10 male students and 12 female students of which 13\% are Malays, 74\% Chinese and 13\% of the indigenous group i.e. Iban.

\subsection{Data Analysis}

Firstly, descriptive statistics-mean, standard deviation, minimum and maximum for the students' scores of argumentation skills was performed. The data were then analysed by using percentage to address the objective of the pilot study which is to evaluate the feasibility of the LAB-MADI module for Grade 10 Biology practical work among students. The students rated the feasibility of the LAB-MADI module for the activities on the seven phases in the MADI model and each eight activities in relation to seen tasks in the rating protocol of strongly disagree, disagree, agree and strongly agree. Lastly, the presentation of the teacher's rating of strongly disagree, disagree, agree and strongly agree on the feasibility of the LAB-MADI module for the students' activities.

\subsection{The LAB-MADI Module}

Argumentation is a specific form of discourse in which reasoned claims made are supported by data or evidence. Practical work could be used to show not only what we know but how we know and that ideas must be argued for. Revision and modifying traditional practical work were made so that traditional practical work were made so that traditional practical work more inquiry and argument oriented. The instructional design of the LAB-MADI module was based on Dick and Carey's instructional design model since this instruction design is suitable for designing practical work teaching and learning environment (Balta, 2015). Thus, this study advocated an argument-driven inquiry teaching and learning based practical work.

The name "LAB-MADI" is a combination of two words; the first word "Lab" 
is the acronym for "laboratory" and the second, "MADI" which is an acronym, refers to "Modified Argument-Driven Inquiry". The developed module revolves around the theme of Investigating Cells as A Unit of Life consists of Topic 1: Introduction to Biology, Topic 2: Cell Structure and Organisation, Topic 3: Movement of Substances across the Plasma Membrane and Topic 4: Chemical Compositions of Cells. The students' understanding of this theme in biology subject is the prerequisite for their understanding of basic biological functions and its content can be easily modified to fit the argument-driven inquiry (Sampson et al., 2014). The topics 3 and 4 were chosen for the purpose of this study.

The MADI model was adapted from the original Argument-Driven Inquiry (ADI) model (Sampson et al., 2014) as an effort to improve the students' ability to participate in the development of scientific argumentation. In addition, the LAB-MADI module was developed to find a more suitable approach to scientific inquiry in the context of teaching science to Malaysian secondary school students in which the module is more of an inquiry-based approach in conducting practical work in the science classroom. The MADI model was grounded in both social and cognitive constructivist theories of learning and cognitive load theory. Vygotsky's Sociocultural Theory provides a foundation for social learning (Pritchard \& Woollard, 2010; Vygotsky, 1978) between the students in the context of practical work and the teacher who assumes the role of a facilitator for the learners. Piaget's theory has similar implications and adds to the richness of constructivism through the acknowledgement of the learners ability to adopt and adapt new knowledge into their schema (Lisi, 2002; Oldfather et al., 1999; Piaget, 1959). Learning can be optimised by considering the way in which information is presented, the complexity of the learned information and students' cognitive ability to process the information (Sweller, 1988). Finally, learning from experiences through hands-on activities in practical work help to form thinking and construct meaning (Glassman, 2001; Lefrancois, 2012).

In brief, the MADI model is an instructional model that draws upon two types of instructional model namely: 1) The 7E model and 2) ADI model informed by the constructivist theory of learning and cognitive load theory. The 7E model were expanded from Bybee's 5E model by (Eisenkraft, 2003), has seven phases 1) Elicit phase, 2) Engage phase, 3) Explore phase, 4) Explain phase, 5) Elaborate phase, 6) Evaluate phase, 7) Extend phase. While ADI model comprised of eight stages-1) Identification of the task and the guiding question, 2) Design a method and collect data, 3) Analyze data and develop a tentative argument, 4) Argumentation session, 5) Explicit and reflective discussion, 6) Write an investigation report, 7) Double blind group peer review and 8) Revises and submit report. This study used the 7E model that systematically guided the stages in the ADI model as this instructional model was chosen because it is widely used in actual classrooms and recommended by the Malaysian Ministry of Education. The teaching and learning steps in MADI model as combination of seven phases of 7E model and its corresponding stages in ADI model are presented in Table 1. 
Table 1. Modified argument-driven inquiry-the MADI model (combination of 7E model and ADI model).

\begin{tabular}{lll}
\hline $\begin{array}{l}\text { Phases of 7E } \\
\text { model }\end{array}$ & $\begin{array}{l}\text { Teaching and learning steps in MADI } \\
\text { model }\end{array}$ & ADI model \\
\hline Elicit & $\begin{array}{l}\text { Step 1: Elicitation students' prior } \\
\text { knowledge }\end{array}$ & 1) Guiding question \\
Engage & $\begin{array}{l}\text { Step 2: Identification of problem statement } \\
\text { and experimental planning }\end{array}$ & $\begin{array}{l}\text { 1) Identification for the task } \\
\text { 2) Design a method }\end{array}$ \\
Explore & $\begin{array}{l}\text { Step 3: Experimentation and collecting } \\
\text { data }\end{array}$ & 2) Collect data \\
Explain & Step 4: Data analysis & 3) Analyze data and develop a tenta- \\
Elaborate & Step 5: Argumentation session & tive argument \\
Evaluate & Step 6: Reflective discussion & 4) Argumentation session \\
Extend & Step 7: Application & 5) Explicit and reflective discussion \\
\hline
\end{tabular}

\subsection{The Intervention}

The students completed three LAB-MADI activities between February and March of 2018. These practical experiments were modified by the researcher and were reviewed by five content experts in terms of their content validity. At the same time, its face and language validity were also verified by three experts. The module was further refined based on the feedback by experts. The checklist of pre-lab preparation was provided to the teacher to help the teacher prepare for the practical lab activities. Additionally, remarks on the quantity of the apparatus and materials needed for each practical work were also included.

All materials to conduct the pilot study (e.g. lesson plans, handouts, pre-test and post-test instruments) were provided by the researcher. The teacher was instructed to follow the lessons plans as closely as possible. In the elicit phase of the LAB-MADI module, the students were provided with a phenomenon which is related to the students' learning experience. The students were facilitated by the teacher making the connection between their previous knowledge of the new concepts in the respective units. For instance, in the second practical activity ("The effect of hypotonic, hypertonic and isotonic solution on plant cells"), a problem-situation about the intention of a farmer to produce fruit pickle using unripe mangoes was presented to the students during the elicit phase. Students were asked to focus on the given natural phenomenon and relate it to their learning experiences. Students tried to relate their previous knowledge about osmosis to the new concepts (tonicity: hypotonic, isotonic and hypertonic) introduced in the unit to explain the related natural phenomenon.

In the engage phase, the students were asked to focus on the group task which was to design an experiment and prepare an investigation proposal with the help of a guiding question. At the beginning of the engage phase, a list of the individual steps in the procedure which were not arranged in any particular order and with unnecessary steps added to the set were prepared for the students. The stu- 
dents were then asked to read the steps and organise them into a logical and sequential order. The students had to differentiate the necessary and unnecessary steps. After a few practical works, additional unnecessary steps were further provided in the set. The students had to brainstorm on how they would plan an experiment to answer the original question, prediction, or hypothesis. This made the practical work resemble a guided inquiry. For instance, in the first practical activity ("The permeability of Plasma Membrane"), the students were asked to read the seven steps and organise them into a logical and sequential order. The students had to differentiate the six necessary steps and one unnecessary steps. The students had to brainstorm how they would plan an experiment to answer the original question, prediction, or hypothesis. Through such an approach, the practical work thus resembled a guided inquiry. The teacher just to take a few minutes to explain how to use specific lab equipment (cork borer, incubator, electronic balance, etc.), how to use specific indicators (Iodine solution, Benedict solution, etc.), how to handle a Visking tubing, or even how to use the electronic balance because students are often unfamiliar with lab equipment. Often if they are familiar with the equipment, they will use it incorrectly or in an unsafe manner.

In the exploration phase, the students carried out the experiment and used the supplies (apparatus and materials) provided appropriately. The students were also asked to collect appropriate data. The students had to apply knowledge of the scientific method and experimental planning by completing the experiment. For instance, in the third practical activity ("The effect of temperature on the Amylase Activity"), students learnt how to deal with the time taken for the iodine solution to remain yellow with the time taken for the amylase reaction to act on the starch.

In the explanation phase, the students generated an argument that provided and supported a claim with evidence in their group. The students were reminded that science is a way of knowing about the world through observation and evidence. The students began their work in small groups by analysing the information they were given about the research question. Together the students formulated a claim in the form of a hypothesis to answer the question. The claim made by the group was the answer to the question. Through group discussion, the students considered the evidence needed to support the conclusion. The evidence component of an argument refers to the measurements or the observations gathered by the students that could be used to support the validity or the acceptability of the conclusion. This evidence could take a number of forms ranging from traditional numerical data (e.g., $\mathrm{pH}$, mass, temperature) to observations (e.g., colour, descriptions of an event). The group members had to explicate on why the evidence supports the conclusion and on why the evidence provided should count as evidence. They then had to complete the argumentation session template that was provided in the module. For instance, in the second practical activity ("The effect of hypotonic, hypertonic and isotonic solution on plant cells"), the students considered the evidences (change of mass or 
length or texture of potato strips) when they studied the effect of different concentration of sugar solution on the plant cells to support the validity of the hypothesis constructed by the group.

In the elaborate phase, the students shared their group argument with others using a round-robin format, where one member of the group stayed at his or her own working station to share the group's ideas while the other group members would go to different groups one at a time to listen to, comment on and criticize the explanation provided by the other groups. The students had to use the argumentation session notes from the presenters and the reviewers during the argumentation session. For instance, in the second practical activity ("The effect of hypotonic, hypertonic and isotonic solution on plant cells"), the students had to defend the hypothesis with the evidences (change of mass or length or texture of potato strips) when they studied the effect of different concentration of sugar solution on the plant cells. They interacted with others besides their own group members in terms of what the evidence (change of mass or length or texture of potato strips) was and how the evidence justified the hypothesis that the concentration of sugar solution which is isotonic to cell sap maintained the mass of plant tissue. They were asked to evaluate the quality of the evidence from the other groups and help to show the reason why what the other groups think might be wrong and why they knew they were right.

In the evaluation phase, the students identified the strengths and limitations of their investigations and discussed the possible ways to improve their future investigations. For instance, in the second practical activity ("The effect of hypotonic, hypertonic and isotonic solution on plant cells"), the teacher had to take a few minutes to stimulate students to suggest the possible ways to improve their future investigations especially when handling the potato strips.

In the extend phase, the students applied the knowledge and the skills to complete the practical assessment. Through this practical assessment, students had to apply science process skills (observing, classifying, measuring \& using numbers, inferring, predicting, communicating, using space and time relations, interpreting data, defining operationally, controlling variables, hypothesising, experimenting) in the written assessment

\subsection{Procedures}

During the introduction day, the students were assigned to a core group for the duration of the pilot study. The students were divided into groups by sorting a spreadsheet first by gender. The results were the formation of six groups which were made up of both male and female students of mixed race. The formative evaluation of the feasibility of the LAB-MADI module was conducted for six days between February and March of 2018. This feasibility session involved twenty-two students along with one biology teacher.

The implementation of LAB-MADI Module's activities which were conducted during the formative evaluation is summarised in Table 2. Before the pilot study was conducted, students were responded to a test (Pre-Test) on their argumen- 
tation skills followed with a briefing with the teacher about the group distribution instructions as well as familiarity with the LAB-MADI content. At the end of the implementation of the LAB-MADI Module, the students were given post-test and a questionnaire to assess the feasibility of the LAB-MADI Module.

Table 2. Intervention schedule.

\begin{tabular}{|c|c|}
\hline Time & Module \& Activity/Phase \\
\hline Introduction & $\begin{array}{l}\text { Pre-Test \& Introduction to the LAB-MADI Module } \\
\text { The permeability of Plasma Membrane } \\
\text { - Elicit Phase-New concepts (Permeability of the Visking tubing). }\end{array}$ \\
\hline $\begin{array}{l}\text { Session } 1 \\
\text { Day } 1\end{array}$ & $\begin{array}{l}\text { - Engage Phase-Students had to differentiate the } 6 \text { necessary steps and } 1 \\
\text { unnecessary step. } \\
\text { - Explore Phase-Students learnt how to deal with the iodine test and Benedict's } \\
\text { test on the two samples of water. }\end{array}$ \\
\hline Session 1 & $\begin{array}{l}\text { - Explain Phase-Students considered the evidences (the interpretation of no colour } \\
\text { change or colour change in iodine test or Benedict's test after } 10 \text { minutes and after } \\
20 \text { minutes) to support the validity of the hypothesis. } \\
\text { - Elaborate Phase-They interacted with others in terms of what the evidence was } \\
\text { and how the evidence justified the hypothesis that the permeability of the }\end{array}$ \\
\hline Day 2 & $\begin{array}{l}\text { Visking tubing depends to the size of the glucose or starch molecules. } \\
\text { - Evaluation Phase-Possible ways to improve their future investigations especially } \\
\text { when handling the Visking tubing to prevent the leakage. } \\
\text { - Extend Phase-The students applied the knowledge and the skills to plan an } \\
\text { experiment as the homework. } \\
\text { The effect of hypotonic, hypertonic and isotonic solution on plant cells } \\
\text { - Elicit Phase-New concepts (tonicity: hypotonic, isotonic and hypertonic). }\end{array}$ \\
\hline $\begin{array}{l}\text { Session } 2 \\
\text { Day } 1\end{array}$ & $\begin{array}{l}\text { - Engage phase-The students had to differentiate the } 5 \text { necessary steps and } 1 \\
\text { unnecessary step. } \\
\text { - Explore Phase-Students learnt how to measure the length or mass of the potato } \\
\text { strips. } \\
\text { - Explain Phase-Students considered the evidences (change of mass or length or } \\
\text { texture of potato strips) to support the validity of the hypothesis. } \\
\text { - Elaborate Phase-They interacted with others in terms of what the evidence was }\end{array}$ \\
\hline $\begin{array}{l}\text { Session } 2 \\
\text { Day } 2\end{array}$ & $\begin{array}{l}\text { and how the evidence justified the hypothesis that the concentration of sugar } \\
\text { solution which is isotonic to cell sap maintained the mass of plant tissue. } \\
\text { - Evaluation Phase-Possible ways to improve their future investigations especially } \\
\text { when handling the potato strips } \\
\text { - Extend Phase-Practical assessment as the homework. } \\
\text { The effect of temperature on the Amylase Activity } \\
\text { - Elicit Phase-New concepts (activation energy, chemical reactions, optimum } \\
\text { temperature). }\end{array}$ \\
\hline $\begin{array}{l}\text { Session } 3 \\
\text { Day } 1\end{array}$ & $\begin{array}{l}\text { - Engage Phase-The students had to differentiate the } 10 \text { necessary steps and } 1 \\
\text { unnecessary step. } \\
\text { - Explore Phase-Students learnt how to deal with the time taken for the iodine } \\
\text { solution remain yellow with the time taken for the amylase reaction to act on the } \\
\text { starch. } \\
\text { - Explain Phase-Students considered the evidences (the time taken for iodine } \\
\text { solution to remain yellow) to support the validity of the hypothesis. } \\
\text { - Elaborate Phase-They interacted with others in terms of what the evidence was }\end{array}$ \\
\hline $\begin{array}{l}\text { Session } 3 \\
\text { Day } 2\end{array}$ & $\begin{array}{l}\text { and how the evidence justified the hypothesis that the optimum temperature of } \\
\text { enzyme activity is } 37^{\circ} \mathrm{C} \text {. } \\
\text { - Evaluation Phase-Possible ways to improve their future investigations when han- } \\
\text { dling the stopwatch to take the time taken for iodine solution to remain yellow. } \\
\text { - Extend Phase-Practical assessment as the homework }\end{array}$ \\
\hline Last Day & Post Test \\
\hline
\end{tabular}




\subsection{Instruments}

The instruments involved were the pre and post-tests in the form of argumentative writing essay which was set in the Argumentation Skills Test, and a questionnaire on the feasibility of the module. The pre- and post-tests were designed to evaluate whether the objective in the module with three research questions could be achieved. Three different data collection instruments were used: 1) Test for Argumentation Skills, 2) student's feasibility questionnaire and record of student actions for each section of the module and 3) teacher's feasibility questionnaire.

The test paper for the Argumentation Skills Test was adapted by the researcher by referring to the Grade 10 Biology Curriculum Specification (MOE 2012), SPM past year examination questions, textbooks, and reference books and according to the design of Sampson, Grooms and Enderle (2011). This argumentative writing essay assessment was developed to assess students' ability to construct and evaluate scientific arguments. In this test, the students were presented with a little argument by a scientist who provided them inaccurate explanation for the data. The students were then asked to respond to the scientist's claim by arguing in support of a countering claim, being sure to include evidence, reasoning and counter argument as part of their argument based on the data and information provided in the question. To assess student ability to construct and evaluate scientific arguments, the researcher modified a base rubric for scientific argument developed by McNeill, Lizotte, Krajcik and Marx (2006) by making it appropriate for use with the standard Biology Curriculum offered in the Malaysian Secondary School System.

The consistency of instrument for Test for Argumentation Skills was determined by using test-retest reliability. The results of the reliability tests showed that the subjective items employed in the instrument had high reliability indices, which were $r=+0.969$ and $p<0.001$ for Test of Argumentation Skills; $r=+0.914$ and $\mathrm{p}<0.001$. The data used in this study were obtained from the results of the pre-test and post-test. The validity and reliability of all the test items have been verified.

\section{Findings}

The descriptive statistics for the pre-test and post-test of students' scores of argumentation skills is presented in Table 3. The summary of students' perspective on the feasibility of the LAB-MADI module for the activities on the seven phases in the MADI model is displayed in Tables 4-10. Based on Table 11, it can be seen that the positive agreement from teacher's perspective on the feasibility of the LAB-MADI module for activity the students.

Research Question 1: What are the effects of the LAB-MADI module on the students' argumentation skills?

Based on Table 3, there were changes in scores between the pre-test (mean = $1.14, \mathrm{SD}=2.145)$ and the post-test $($ mean $=9.77, \mathrm{SD}=10.854)$. The students 
were directed to respond to the scientist's claim by arguing in support of a countering claim and include evidence and reasoning and counter argument as part of their argument based on the data and information provided in the question. Table 3 reveals that the highest and the lowest scores were $5 \%$ and $0 \%$ respectively during the pre-test and $40 \%$ and $0 \%$ respectively during the post-test.

Table 3. The descriptive statistics of students' scores of argumentation skills.

\begin{tabular}{ccccccc}
\hline Scale & Test & N & Mean & SD & Minimum & Maximum \\
\hline $\begin{array}{c}\text { Test scores of students' } \\
\text { argumentation skills }\end{array}$ & Pre-test & 22 & 1.14 & 2.145 & 0 & 5 \\
\hline
\end{tabular}

Table 4. Students' perspective on the feasibility of the LAB-MADI module for the activity in the elicit phase.

\begin{tabular}{llllll}
\hline No & Item & $\begin{array}{l}\text { Strongly } \\
\text { disagree } \\
(\%)\end{array}$ & $\begin{array}{l}\text { Disagree } \\
(\%)\end{array}$ & Agree (\%) $\begin{array}{l}\text { Strongly } \\
\text { agree (\%) }\end{array}$ \\
\hline 1 & $\quad \begin{array}{l}\text { I understand the given phenomenon. } \\
\begin{array}{l}\text { I am able to give more examples related to } \\
\text { the given phenomenon. }\end{array}\end{array}$ & 0 & 0 & 47.8 & 52.2 \\
& & 4.3 & 78.3 & 0 \\
\hline
\end{tabular}

Table 5. Students' perspective on the feasibility of the LAB-MADI module for the activity in the engage phase.

\begin{tabular}{|c|c|c|c|c|c|}
\hline No & Item & $\begin{array}{l}\text { Strongly } \\
\text { disagree } \\
(\%)\end{array}$ & $\begin{array}{l}\text { Disagree } \\
(\%)\end{array}$ & Agree (\%) & $\begin{array}{l}\text { Strongly } \\
\text { agree (\%) }\end{array}$ \\
\hline 1 & $\begin{array}{l}\text { I am able to identify the problem statement } \\
\text { of the investigation. }\end{array}$ & 0 & 0 & 69.6 & 30.4 \\
\hline 2 & $\begin{array}{l}\text { I am able to identify the hypothesis of the } \\
\text { investigation. }\end{array}$ & 0 & 0 & 65.2 & 34.8 \\
\hline 3 & $\begin{array}{l}\text { I know the function of the apparatus and } \\
\text { materials used in the investigation. }\end{array}$ & 0 & 4.3 & 60.9 & 34.8 \\
\hline 4 & $\begin{array}{l}\text { I am able to arrange the procedure without } \\
\text { assistance. }\end{array}$ & 0 & 26.1 & 43.5 & 30.4 \\
\hline 5 & $\begin{array}{l}\text { I am able to determine the technique of } \\
\text { collecting the responding variable. }\end{array}$ & 0 & 39.1 & 56.5 & 4.3 \\
\hline 6 & $\begin{array}{l}\text { I am able to design tables for data } \\
\text { presentation. }\end{array}$ & 0 & 8.7 & 65.2 & 26.1 \\
\hline
\end{tabular}

Table 6. Students' perspective on the feasibility of the LAB-MADI module for the activity in the explore phase.

\begin{tabular}{|c|c|c|c|c|c|}
\hline No & Item & $\begin{array}{l}\text { Strongly } \\
\text { disagree } \\
(\%)\end{array}$ & $\begin{array}{l}\text { Disagree } \\
(\%)\end{array}$ & Agree (\%) & $\begin{array}{l}\text { Strongly } \\
\text { agree (\%) }\end{array}$ \\
\hline 1 & $\begin{array}{l}\text { I am able to conduct investigations according } \\
\text { to the planned procedures scientifically. }\end{array}$ & 0 & 21.7 & 65.2 & 13.0 \\
\hline 2 & I am able to collect data scientifically. & 0 & 8.7 & 69.6 & 21.7 \\
\hline
\end{tabular}


Table 7. Students' perspective on the feasibility of the LAB-MADI module for the activity in the explain phase.

\begin{tabular}{|c|c|c|c|c|c|}
\hline No & Item & $\begin{array}{l}\text { Strongly } \\
\text { disagree } \\
(\%)\end{array}$ & $\begin{array}{l}\text { Disagree } \\
(\%)\end{array}$ & Agree (\%) & $\begin{array}{l}\text { Strongly } \\
\text { agree (\%) }\end{array}$ \\
\hline 1 & $\begin{array}{l}\text { I am able to differentiate observation from } \\
\text { inference. }\end{array}$ & 0 & 13.0 & 60.9 & 26.1 \\
\hline 2 & I am able to analyses data. & 0 & 4.3 & 52.2 & 43.5 \\
\hline 3 & $\begin{array}{l}\text { I am able to generate evidence based on } \\
\text { data. }\end{array}$ & 0 & 8.7 & 56.5 & 34.8 \\
\hline 4 & $\begin{array}{l}\text { I am able to generate justification based on } \\
\text { evidence. }\end{array}$ & 0 & 8.7 & 60.9 & 30.4 \\
\hline 5 & $\begin{array}{l}\text { I am able to explain the importance of the } \\
\text { evidence. }\end{array}$ & 0 & 21.7 & 43.5 & 34.8 \\
\hline 6 & I am able to generate the tentative argument. & 0 & 21.7 & 52.2 & 26.1 \\
\hline
\end{tabular}

Table 8. Students' perspective on the feasibility of the LAB-MADI module for the activity in the expand phase.

\begin{tabular}{|c|c|c|c|c|c|}
\hline No & Item & $\begin{array}{l}\text { Strongly } \\
\text { disagree } \\
(\%)\end{array}$ & $\begin{array}{l}\text { Disagree } \\
(\%)\end{array}$ & Agree $(\%)$ & $\begin{array}{l}\text { Strongly } \\
\text { agree }(\%)\end{array}$ \\
\hline 1 & $\begin{array}{l}\text { I know my role during the argumentation } \\
\text { session. }\end{array}$ & 0 & 8.7 & 52.2 & 39.1 \\
\hline 2 & $\begin{array}{l}\text { I am able to evaluate the content of the } \\
\text { hypothesis. }\end{array}$ & 0 & 4.3 & 56.5 & 39.1 \\
\hline 3 & $\begin{array}{l}\text { I am able to evaluate the quality of the } \\
\text { hypothesis. }\end{array}$ & 0 & 8.7 & 69.6 & 21.7 \\
\hline 4 & $\begin{array}{l}\text { I am able to evaluate the content of the } \\
\text { evidence. }\end{array}$ & 0 & 8.7 & 73.9 & 17.4 \\
\hline 5 & $\begin{array}{l}\text { I am able to evaluate the quality of the } \\
\text { evidence. }\end{array}$ & 0 & 4.3 & 78.3 & 17.4 \\
\hline 6 & $\begin{array}{l}\text { I am able to evaluate the content of the } \\
\text { justification. }\end{array}$ & 0 & 17.4 & 65.2 & 17.4 \\
\hline 7 & $\begin{array}{l}\text { I am able to evaluate the quality of the } \\
\text { justification. }\end{array}$ & 0 & 13.0 & 69.6 & 17.4 \\
\hline
\end{tabular}

Table 9. Students' perspective on the feasibility of the LAB-MADI module for the activity in the evaluate phase.

\begin{tabular}{llllll}
\hline No & Item & $\begin{array}{l}\text { Strongly } \\
\text { disagree } \\
(\%)\end{array}$ & $\begin{array}{l}\text { Disagree } \\
(\%)\end{array}$ & $\begin{array}{l}\text { Agree } \\
(\%)\end{array}$ & $\begin{array}{l}\text { Strongly } \\
\text { agree (\%) }\end{array}$ \\
\hline 1 & I know my strength in my investigation. & 0 & 8.7 & 69.6 & 21.7 \\
2 & I know my weakness in my investigation. & 0 & 4.3 & 56.5 & 39.1 \\
3 & I know why the wrong answer is wrong. & 0 & 17.4 & 69.6 & 13.0 \\
4 & I know why the right answer is right. & 0 & 4.3 & 69.6 & 26.1 \\
\hline
\end{tabular}


Table 10. Students' perspective on the feasibility of the LAB-MADI module for the activity in the extend phase.

\begin{tabular}{llllll}
\hline No & Item & $\begin{array}{l}\text { Strongly } \\
\text { disagree } \\
(\%)\end{array}$ & $\begin{array}{l}\text { Disagree } \\
(\%)\end{array}$ & $\begin{array}{l}\text { Agree } \\
(\%)\end{array}$ & $\begin{array}{l}\text { Strongly } \\
\text { agree (\%) }\end{array}$ \\
\hline $1 \quad \begin{array}{l}\text { I am able to answer the practical } \\
\text { assessment. }\end{array}$ & 0 & 8.7 & 47.8 & 43.5 \\
2 & I am able to plan the experiment. & 0 & 30.4 & 60.9 & 8.7 \\
\hline
\end{tabular}

Table 11. Teacher's perspective on the feasibility of the LAB-MADI module for students' activities.

\begin{tabular}{|c|c|c|c|c|c|}
\hline No & Item & $\begin{array}{l}\text { Strongly } \\
\text { disagree }\end{array}$ & Disagree & Agree & $\begin{array}{l}\text { Strongly } \\
\text { agree }\end{array}$ \\
\hline 1 & $\begin{array}{l}\text { Students are able to carry out the practical } \\
\text { work as they work through the module. }\end{array}$ & & & I & \\
\hline 2 & $\begin{array}{l}\text { Students are able to state the aim of the } \\
\text { investigation of the practical work as they } \\
\text { work through the module. }\end{array}$ & & & & I \\
\hline 3 & $\begin{array}{l}\text { Students are able to form evidence to support } \\
\text { the hypothesis in writing as they work through } \\
\text { the module. }\end{array}$ & & & & I \\
\hline 4 & $\begin{array}{l}\text { Students are able to form evidence to support } \\
\text { the hypothesis orally as they work through the } \\
\text { module. }\end{array}$ & & & I & \\
\hline 5 & $\begin{array}{l}\text { Students are able to argue based on evidence to } \\
\text { support the hypothesis in wiring as they work } \\
\text { through the module. }\end{array}$ & & & & I \\
\hline 6 & $\begin{array}{l}\text { Students are able to argue based on evidence to } \\
\text { support the hypothesis orally as they work } \\
\text { through the module. }\end{array}$ & & & I & \\
\hline 7 & $\begin{array}{l}\text { Students are able to evaluate the arguments of } \\
\text { other groups during the argumentation session } \\
\text { as they work through the module. }\end{array}$ & & & I & \\
\hline
\end{tabular}

Research Question 2: What is the students' perspective on the feasibility of the LAB-MADI module?

Table 4 shows students' perspective on the feasibility of LAB-MADI activity during the elicit phase in the form of percentage of agreement. All 22 students agreed and strongly agreed that they understood the given phenomenon while $78.3 \%$ of the students agreed that they were able to give more examples related to the given phenomenon. The range of agreement among students on the feasibility of the LAB-MADI activity during the elicit phase was between $78.3 \%$ to $100.0 \%$. Therefore, the feasibility of LAB-MADI module was high among the students for the activity in the elicit phase.

Table 5 shows the students' perspective on the feasibility of the LAB-MADI activity during engage phase in the form of percentage of agreement. All $22 \mathrm{stu}-$ dents agreed and strongly agreed that they were able to identify the problem 
statement and hypothesis of the investigation. About $95.7 \%$ of the students agreed and strongly agreed that they knew the function of the apparatus and materials used in the investigation. About $73.0 \%$ of the students agreed and strongly agreed that they were able to arrange the procedure without assistance. About $60.8 \%$ of the students agreed and strongly agreed that they were able to determine the technique of collecting the responding variable while $91.3 \%$ of the students were able to design tables for data presentation. The range of agreement among the students on the feasibility of the LAB-MADI activity during the engage phase was between $60.8 \%$ and $100.0 \%$. Therefore, the feasibility of the LAB-MADI module was high among the students for the activity in the engage phase.

Table 6 shows the students' perspective on the feasibility of the LAB-MADI activity during the explore phase in the form of percentage of agreement. About $78.2 \%$ of the students agreed and strongly agreed that they were able to conduct investigations according to the planned procedures scientifically while $91.3 \%$ students agreed and strongly agreed that they were able to collect data scientifically. The range of agreement among the students on the feasibility of LAB-MADI module for the activity in the explore phase was between $78.2 \%$ and $91.3 \%$. Therefore, the feasibility of the LAB-MADI module was high among the students in for the activity in the explore phase.

Table 7 shows the students' perspective on the feasibility of the LAB-MADI activity during the explain phase in the form of percentage of agreement. About $87.0 \%$ of the students agreed and strongly agreed that they were able to differentiate observation from inference. About $95.7 \%$ of the students agreed and strongly agreed that they were able to analyse data while $91.3 \%$ of the students agreed and strongly agreed that they were able to generate evidence based on data and generate justification based on evidence. About $78.3 \%$ of the students agreed and strongly agreed that they were able to explain the importance of the evidence and generate the tentative argument. The range of agreement among students on the feasibility of the LAB-MADI module for the activity in the explain phase was between $78.3 \%$ and $95.7 \%$. Therefore, the feasibility of the LAB-MADI module was high among the students for the activity in explain phase.

Table 8 shows the students' perspective on the feasibility of the LAB-MADI activity during the expand phase in the form of percentage of agreement. About 91.9\% of the students agreed and strongly agreed that they knew their role during the argumentation session and they were able to evaluate the quality of the hypothesis as well as the content of the evidence, while $95.6 \%$ of the students agreed and strongly agreed that they were able to evaluate the content of the hypothesis and the quality of the evidence. About $82.6 \%$ of the students agreed and strongly agreed that they were able to evaluate the content of the justification, while $87.0 \%$ of the students agreed and strongly agreed that they were able to evaluate the quality of the justification. The range of agreement among the stu- 
dents on the feasibility of the LAB-MADI module for the activity in the expand phase was between $82.6 \%$ and $95.6 \%$. Therefore, the feasibility of the LAB-MADI module was high among the students for the activity in the expand phase.

Table 9 shows the students' perspective on the feasibility of the LAB-MADI activity during the evaluation phase in the form of percentage of agreement. About $91.3 \%$ of the students agreed and strongly agree that they knew their strength in their investigation while $95.6 \%$ of the students agreed and strongly agreed that they knew their weakness in their investigation. About $82.6 \%$ of the students agreed and strongly agreed that they knew why the wrong answer was wrong, while $95.7 \%$ of the students agreed and strongly agreed that they knew why right answer was right. The range of agreement among the students on the feasibility of the LAB-MADI module for the activity in the evaluation phase was between $82.6 \%$ and $95.7 \%$. Therefore, the feasibility of the LAB-MADI module was high among the students for the activity in the evaluation phase.

Table 10 shows the students' perspective on the feasibility of the LAB-MADI module for the activity in the extend phase in the form of percentage of agreement. $91.3 \%$ of the students agreed and strongly agreed that they were able to answer the practical assessment while $69.6 \%$ of the students agreed and strongly agreed that they were able to plan the experiment. The range of agreement among the students for the feasibility of the LAB-MADI module for the activity in the extend phase was in the range of $69.6 \%$ to $91.3 \%$. Hence, the feasibility of the LAB-MADI module for the activity in the extend phase was high among the students.

Research Question 3: What is the teachers' perspective on the feasibility of the LAB-MADI module for Grade 10 students?

Table 11 shows that the teacher in the pilot study agreed that the students were able to carry out the practical work, form evidence to support the hypothesis and argue based on evidence to support the hypothesis orally as well as evaluate the arguments of other groups during the argumentation session when the students worked through the module. The teacher strongly agreed that the students were able to state the aim of the investigation of the practical work, form evidence to support the hypothesis and argue based on evidence to support the hypothesis in writing as they worked through the module. Therefore, the teacher showed positive acceptance of the feasibility of the LAB-MADI module for the students.

Overall, the range of agreement among the students for the feasibility of the LAB-MADI module for the activities based on the seven phases in the MADI model was in the range of $69.6 \%$ to $100.0 \%$. Hence, the feasibility of the LAB-MADI module for the activity in the MADI model was high among the students. The teacher also showed positive acceptance in terms of how the implementation of the Lab-MADI module in session 1 to session 3 has helped her students' to improve in terms of their ability, skills and knowledge in Biology with one exception of time limitation. 


\section{Discussion}

The students' ability to write arguments significantly increased after explicit instruction scientific argument during the practical work. The students had a mean score of 1.14 out of 20 for argumentative writing in the pre-test which was given before the implementation of the LAB-MADI module. However, after the implementation of the LAB-MADI module, the students' mean score for scientific argumentative writing increased to 9.77 out of 20 in the post-test. The students' mean scores were statistically higher in the post-test but the results were still considered below the mid score in relation to the total score. The students did not show a remarkable improvement in their argumentation skills in their argumentative essays. In their written test, the students were asked to write an argument to respond to the scientist's claim by arguing in support of a countering claim, being sure to include evidence and rationale as part of their argument based on the data and information provided in the question. The students tended to repeat the question statement rather than state their claim clearly to refute the scientist's claim. The majority of the students still could not utilise the data in the question paper to generate evidence to support their ideas. The students used their existing knowledge to support their chosen explanation rather than transforming the available data into evidence to support their written arguments. In post-test, nine out of twenty-two students had provided inaccurate claim as their answer in relation to the concepts of diffusion and osmosis concepts.

Heng, Surif and Seng (2014) found that mastery of scientific argumentation was unsatisfactory for all the students in their study regardless of individuals or groups. Students tend to provide details about their methods or observations rather than use appropriate evidence and reasoning to support their claim (Zeidler, 1997). Additionally, students would commonly use opinion instead of evidence and data to support a claim. With the LAB-MADI module, students could learn to provide appropriate evidence and the necessary data to support a claim in scientific arguments (Sandoval \& Millwood, 2005). Sampson et al. (2011) found that students were providing reasons and evidence with concept but they still could not rationalise the use of these evidences in supporting their claims. Students are more likely to give unclear explanations or just give their observations rather than provide a basic causal mechanism for the phenomenon under their investigation (McNeill et al., 2006).

The students' view of the LAB-MADI module was also identified in the pilot study. The students expressed positive feedback on the benefits of the argumentation process in the LAB-MADI module. The students stated that the practical work performed under the LAB-MADI module motivated them to think and to learn better. This finding is actually an expected result for Argument-Driven Inquiry which provides various opportunities for social interaction (Sampson \& Gleim, 2009). Nonetheless, one challenge is finding effective ways to support both teachers and students in constructing why the right answers are right, with 
much less emphasis placed on why the wrong answers are wrong (Henderson et al., 2018). As students were given opportunities to generate, challenge, justify, and defend a claim in the activities of the LAB-MADI module, it is expected that the students would become not only more aware of their own voices but also the voices of others through active listening.

The teacher also gave positive comments after the implementation of the LAB-MADI module in session 1, session 2 and session 3. The feedback indicated that the module provided opportunity for students to master the concepts of diffusion and osmosis concepts and it also increased students' ability in science process skills and argumentation skills. The students were given the chance to think critically after the practical work through the argumentation session. In the teacher's opinion, this module has helped her significantly in the process of delivering teaching during practical work and has provided the students to explore science learning not only in their respective groups but also with the members of the other groups. Additionally, the teacher felt that the students were able to master the topics containing abstract concepts much faster than the typical traditional way of teaching practical work. Indirectly, this also increased the students' focus in the practical work.

The teacher noted a disadvantage during the pilot studying; the teacher indicated that they did not have enough time to prepare good and bad samples of argumentation. There were students that who could not generate correct statements of evidence as they needed more guidance including samples of good and bad arguments; however, the teacher lacked time to prepare them. Establishing materials and the pedagogic strategies to facilitate and support argumentation in the classroom are very important (Osborne et al., 2004). Arguably, if the activities are too complex, the teachers might easily lose interest in the usage of this module. Studies have reported that students did not have much opportunity to argue because primary school and secondary schools teachers (Sampson \& Blanchard, 2012) lacked resources on the teaching strategies of argumentation as well as ideas to implement the inquiry based approach in their science classroom (Choi, Klein, \& Hershberger, 2014; Sampson \& Blanchard, 2012).

Education curriculum is necessary to better support teachers in implementing argumentation in their teaching (McNeill \& Pimentel, 2010). McNeill et al. (2016) further suggested that support resources that meet the curriculum should be provided to enhance teacher confidence in teaching. Thus, teachers need materials and support to integrate argumentation into the teaching and learning of science. Sampson and Blanchard (2012) also suggested that adoption of adapted research strategies and adaptation in classroom contexts would encourage more student engagement in scientific submissions in the classroom.

Biology educators could use the experiences gained through the use of the LAB-MADI module as a foundation to help make the aspects of scientific argument explicit in science practical work. Over time, this should help biology teachers develop the knowledge and skills they would need to integrate more 
argumentation into their science classroom. In short, the feasibility of using this LAB-MADI Module to provide students opportunities for scaffolding and collaborative work would greatly facilitate development of students' argumentation skills which are vital in science learning.

\section{Conclusion}

The intent of this paper is to investigate the feasibility of the instructions and activities in the LAB-MADI module for students and teachers from the perspective of students and teachers. The LAB-MADI module was constructed as an effort to improve students' ability to participate in the development of scientific argumentation. Based on the findings, it is evident that the introduction of the LAB-MADI module enabled the biology teacher to use the various instructional resources developed in the module to promote scientific argumentation in practical biology among a small sample size of Grade 10 students. Furthermore, the MADI model may have the potency to enhance the argumentation skills of students especially argumentation in writing. In this pilot study, by participating in argumentation sessions and production of spoken and written argument, the students were able to improve their argumentation skills. Findings from the analysis show that this module has very good feasibility based on rating of teacher and students. This study contributes by making it feasible for biology educators to implement learning strategies which involve scaffolding in science practical work to develop students' understanding of science concept, writing ability as well as argumentation skills via the use of a module.

Based on the result of the pilot study, in order to overcome the issue of duration of time that was highlighted and raised during pilot study, the focus of the argumentation session will be on either one of the three practical assessments on comparing two sets of data, evaluating the reliability of an experiment and assessing the validity of data. Furthermore, the template of sentence starters for the argumentation session which will be added to the LAB-MADI Module would also help group members in starting their conversation within the same group and different groups. With this improvement, future research that examines the efficacy of the MADI instructional model in comparison to other approaches using quasi-experimental design involving larger sample size Grade 10 students is needed to determine the effectiveness of the LAB-MADI module on student argumentation skills.

\section{Conflicts of Interest}

The authors declare no conflicts of interest regarding the publication of this paper.

\section{References}

Abdullah, A., \& Francis Peters, R. (2015). Malaysia's Post-PISA 2012 Direction. International Journal of Culture and History, 1, 15-20. 
https://doi.org/10.18178/ijch.2015.1.1.003

Akarsu, B., Bayram, K., Slisko, J., \& Cruz, A. C. (2013). Understanding Elementary Students' Argumentation Skills through Discrepant Event "Marbles in the Jar". International Journal of Scientific Research in Education, 6, 221-232.

Balta, N. (2015). A Systematic Planning for Science Laboratory Instruction: Research-Based Evidence. Eurasia Journal of Mathematics, Science \& Technology Education, 11, 957-969. https://doi.org/10.12973/eurasia.2015.1366a

Becker, R. E. (2014). Explicit Instruction of Scientific Explanation and Argument in an Undergraduate Introductory Biology Laboratory Course Using the Claim, Evidence and Reasoning Framework. PhD Thesis, Baton Rouge, LA: Louisiana State University.

Berland, L. K., \& Hammer, D. (2012). Framing for Scientific Argumentation. Journal of Research in Science Teaching, 49, 68-94. https://doi.org/10.1002/tea.20446

Cengiz, E., \& Ayvaci, H. S. (2017). Analysing the Feedback that Secondary School Science Teachers Provide for Student Errors That Show Up in Their Lessons. Journal of Turkish Science Education, 14, 109-124.

Çetİn, P., Metİn, D., \& Kaya, E. (2016). A New Approach to Laboratory Applications: Argument-Driven Inquiry. Ahi Evran Üniversitesi Kırşehir Eğitim Fakültesi Dergisi (KEFAD), 17, 223-243.

Choi, A., Klein, V., \& Hershberger, S. (2014). Success, Difficulty, and Instructional Strategy to Enact an Argument-Based Inquiry Approach: Experiences of Elementary Teachers. International Journal of Science and Mathematics Education, 13, 991-1011. https://doi.org/10.1007/s10763-014-9525-1

Clark, D. B., \& Sampson, V. (2007). Personally-Seeded Discussions to Scaffold Online Argumentation. International Journal of Science Education, 29, 253-277. https://doi.org/10.1080/09500690600560944

Clark, D. B., \& Sampson, V. (2008). Assessing Dialogic Argumentation in Online Environments to Relate Structure, Grounds, and Conceptual Quality. Journal of Research in Science Teaching, 45, 293-321. https://doi.org/10.1002/tea.20216

Demircioglu, T., \& Ucar, S. (2015). Investigating the Effect of Argument-Driven Inquiry in Laboratory Instruction. Educational Sciences: Theory \& Practice, 15, 267-283. https://doi.org/10.12738/estp.2015.1.2324

Dick, W., Carey, L., \& Carey, J. O. (2015). The Systematic Design of Instruction (8th ed.). Boston, MA: Pearson.

Driver, R., Newton, P., \& Osborne, J. (2000). Establishing the Norms of Scientific Argumentation in Classrooms. Science Education, 84, 287-312. https://doi.org/10.1002/(SICI)1098-237X(200005)84:3<287::AID-SCE1>3.0.CO;2-A

Duschl, R. A., \& Osborne, J. (2002). Supporting and Promoting Argumentation Discourse in Science Education. Studies in Science Education, 38, 39-72. https://doi.org/10.1080/03057260208560187

Eisenkraft, A. (2003). Expanding the 5E Model. The Science Teacher, 70, 56-59.

Enderle, P. J., Grooms, J. A., \& Williams, K. (2012). The Development of Science Proficiency in High School Chemistry Students Engaged in Argument Focused Instruction. In 2012 Annual Meeting for the American Educational Research Association (pp. 1-14). Vancouver: British Columbia.

Enderle, P. J., Grooms, J., \& Sampson, V. (2013). The Use of Argumentation in Science Education to Promote the Development of Science Proficiency: A Comparative Case Study. In Paper Presented Conference of the Society for Research on Educational Effectiveness (p. 13). Washington DC: SREE. 
https://files.eric.ed.gov/fulltext/ED564062.pdf

Fisher, K. M., Williams, K. S., \& Lineback, J. E. (2011). Osmosis and Diffusion Conceptual Assessment. CBE Life Sciences Education, 10, 418-429. https://doi.org/10.1187/cbe.11-04-0038

Foong, C. C., \& Daniel, E. G. S. (2013). Students' Argumentation Skills across Two Socio-Scientific Issues in a Confucian Classroom: Is Transfer Possible? International Journal of Science Education, 35, 2331-2355. https://doi.org/10.1080/09500693.2012.697209

Friedler, Y., Amir, R., \& Tamir, P. (1987). High School Students' Difficulties in Understanding Osmosis. International Journal of Science Education, 9, 541-551. https://doi.org/10.1080/09500693.2012.697209

Glassman, M. (2001). Dewey and Vygotsky: Society, Experience, and Inquiry in Educational Practice. Educational Researcher, 30, 3-14. https://doi.org/10.3102/0013189x030004003

Gultepe, N., \& Kilic, Z. (2015). Effect of Scientific Argumentation on the Development of Scientific Process Skills in the Context of Teaching Chemistry. International Journal of Environmental and Science Education, 10, 111-132. https://doi.org/10.1037/t51058-000

Hasni, A., Roy, P., \& Dumais, N. (2016). The Teaching and Learning of Diffusion and Osmosis: What Can We Learn from Analysis of Classroom Practices? A Case Study. Eurasia Journal of Mathematics, Science \& Technology Education, 12, 1507-1531.

Hasnunidah, N., Susilo, H., Henie, M. I., \& Sutomo, H. (2015). Argument-Driven Inquiry with Scaffolding as the Development Strategies of Argumentation and Critical Thinking Skills of Students in Lampung, Indonesia. American Journal of Educational Research, 3, 1195-1192.

Henderson, J. B., McNeill, K. L., González-Howard, M., Close, K., \& Evans, M. (2018). Key Challenges and Future Directions for Educational Research on Scientific Argumentation. Journal of Research in Science Teaching, 55, 5-14.

https://doi.org/10.1002/tea.21412

Heng, L. L., \& Surif, J. (2013a). Penghujahan Saintifik: Penguasaan Pelajar dalam Konsep Asid dan Bes Secara Individu dan Kumpulan. In International Seminar on Quality and Affordable Education (pp. 40-51). Johor Bahru: UTM.

Heng, L. L., \& Surif, J. (2013b). Penghujahan Saintifik: Memahami Perlaksanaannya dalam Proses Pengajaran dan Pembelajaran Kimia. Jurnal Teknologi, 65, 1-8. https://doi.org/10.11113/jt.v65.1549

Heng, L. L., Surif, J., \& Seng, C. H. (2014). Individual versus Group Argumentation: Student's Performance in a Malaysian Context. International Education Studies, 7, 109-124. https://doi.org/10.5539/ies.v7n7p109

Heng, L. L., Surif, J., \& Seng, C. H. (2015a). Malaysian Students' Scientific Argumentation: Do Groups Perform Better than Individuals? International Journal of Science Education, 37, 505-528. https://doi.org/10.1080/09500693.2014.995147

Heng, L. L., Surif, J., \& Seng, C. H. (2015b). Mastery of Scientific Argumentation on the Concept of Neutralization in Chemistry: A Malaysian Perspective. Malaysian Journal of Learning and Instruction, 12, 85-101. https://doi.org/10.32890/mjli2015.12.5

Hofstein, A., \& Kind, P. M. (2012). Learning in and from Science Laboratories. In B. J. Fraser, K. Tobin, \& C. J. McRobbie (Eds.), Second International Handbook of Science Education (pp. 189-208). Dordrecht: Springer. https://doi.org/10.1007/978-1-4020-9041-7_15

Jiménez-Aleixandre, M. P., Rodríaguez, A. B., \& Duschl, R. A. (2000). “Doing the Lesson” 
or "Doing Science": Argument in High School Genetics. Science Education, 84, 757-792. https://doi.org/10.1002/1098-237X(200011)84:6<757::AID-SCE5>3.0.CO;2-F

Kim, H., \& Song, J. (2006). The Features of Peer Argumentation in Middle School Students' Scientific Inquiry. Research in Science Education, 36, 211-233. https://doi.org/10.1007/s11165-005-9005-2

Lee, S. S., \& Daniel, E. G. S. (2012). Development and Administration of a Two-Tier Diagnotic Test to Investigate Students' Coherent Understanding of the Movement of Substances across the Plasma Membrane. In A. N. Md Zain, \& D. R. Peter (Eds.), Transforming School Science Education in the 21st Century (pp. 332-345). Penang: SEAMEO-RECSAM Publications.

Lefrancois, G. R. (2012). Teories of Human Learning 6e: What the Professor Said (6th ed.). Belmont, USA: Wadsworth.

Lisi, R. De. (2002). From Marbles to Instant Messenger: Implications of Piaget's Ideas about Peer Learning. Theory into Practice, 41, 26-32. https://doi.org/10.1207/s15430421tip4101_2

Mcneill, K. L. (2009). Teachers' Use of Curriculum to Support Students in Writing Scientific Arguments to Explain Phenomena. Science Education, 93, 233-268. https://doi.org/10.1002/sce.20294

McNeill, K. L., \& Pimentel, D. S. (2010). Scientific Discourse in Three Urban Classrooms: The Role of the Teacher in Engaging High School Students in Argumentation. Science Education, 94, 203-229. https://doi.org/10.1002/sce.20364

McNeill, K. L., Katsh-Singer, R., González-Howard, M., \& Loper, S. (2016). Factors Impacting Teachers' Argumentation Instruction in Their Science Classrooms. International Journal of Science Education, 38, 2026-2046. https://doi.org/10.1080/09500693.2016.1221547

Mcneill, K. L., Lizotte, D. J., Krajcik, J., \& Marx, R. W. (2006). Supporting Students' Construction of Scientific Explanations by Fading Materials Scaffolds in Instructional Materials. The Journal of the Learning Science, 15, 153-191. https://doi.org/10.1207/s15327809j1s1502_1

Millar, R., \& Abrahams, I. (2009). Practical Work: Making It More Effective. School Science Review, 91, 59-64.

MOE (2012). Integrated Curriculum for Secondary Schools: Curriculum Specifications Biology form 4. Putrajaya: Curriculum Development Centre Ministry of Education Malaysia.

Newton, P., \& Driver, R. (1999). The Place of Argumentation in the Pedagogy of School Science. International Journal of Science Education, 21, 553-576. https://doi.org/10.1080/095006999290570

Nur, S., Mahmud, D., Nasri, N. M., Samsudin, M. A., \& Halim, L. (2018). Science Teacher Education in Malaysia: Challenges and Way Forward. Asia-Pacific Science Education, 4, 1-12. https://doi.org/10.1186/s41029-018-0026-3

Nussbaum, E. M., \& Sinatra, G. M. (2003). Argument and Conceptual Engagement. Contemporary Educational Psychology, 28, 384-395. https://doi.org/10.1016/S0361-476X(02)00038-3

Oldfather, P., West, J., White, J., \& Wilmarth, J. (1999). Learning through Children's Eyes: Social Constructivism and the Desire to Learn. Washington DC: American Psychological Association. https://doi.org/10.1037/10328-000

Osborne, J. (2012). The Role of Argument: Learning How to Learn in School Science. In B. J. Fraser, K. Tobin, \& C. J. McRobbie (Eds.), Second International Handbook of 
Science Education (pp. 933-950). Dordrecht: Springer.

https://doi.org/10.1007/978-1-4020-9041-7_62

Osborne, J. (2013). The 21st Century Challenge for Science Education: Assessing Scientific Reasoning. Thinking Skills and Creativity, 10, 265-279.

https://doi.org/10.1016/j.tsc.2013.07.006

Osborne, J. (2015). Practical Work in Science: Misunderstood and Badly Used? School Science Review, 96, 16-24.

Osborne, J. F. (2010). An Argument for Arguments in Science Classes. Phi Delta Kappan, 91, 62-65. https://doi.org/10.1177/003172171009100413

Osborne, J., Erduran, S., \& Simon, S. (2004). Enhancing the Quality of Argumentation in School Science. Journal of Research in Science Teaching, 41, 994-1020. https://doi.org/10.1002/tea.20035

Osborne, J., Simon, S., Christodoulou, A., Howell-Richardson, C., \& Richardson, K. (2013). Learning to Argue: A Study of Four Schools and Their Attempt to Develop the Use of Argumentation as a Common Instructional Practice and Its Impact on Students. Journal of Research in Science Teaching, 50, 315-347. https://doi.org/10.1002/tea.21073

Peen, T. Y., \& Arshad, M. Y. (2013). Collaborative and Self-Directed Learning Processes: A Case Study in Malaysian Chemistry PBL Lesson. In International Seminar on Quality and Affordable Education (pp. 76-84). Johor Bahru: UTM.

Peen, T. Y., \& Arshad, M. Y. (2014). Teacher and Student Questions: A Case Study in Malaysian Secondary School Problem-Based Learning. Asian Social Science, 10, 174. https://doi.org/10.5539/ass.v10n4p174

Piaget, J. (1959). The Language and Thought of the Child (3rd ed.). London: Routledge.

Pritchard, A., \& Woollard, J. (2010). Psychology for the Classroom: Constructivism and Social Learning. Florence, KY: Routledge. https://doi.org/10.4324/9780203819166

Reiss, M. J., Millar, R., \& Osborne, J. (1999). Beyond 2000: Science/Biology Education for the Future. Journal of Biological Education, 33, 68-70.

https://doi.org/10.1080/00219266.1999.9655644

Sampson, V., \& Blanchard, M. R. (2012). Science Teachers and Scientific Argumentation: Trends in Views and Practice. Journal of Research in Science Teaching, 49, 1122-1148. https://doi.org/10.1002/tea.21037

Sampson, V., \& Clark, D. (2009). The Impact of Collaboration on the Outcomes of Scientific Argumentation. Science Education, 93, 448-484. https://doi.org/10.1002/sce.20306

Sampson, V., \& Gleim, L. (2009). Argument-Driven Inquiry to Promote the Understanding of Important Concepts \&Practices in Biology. The American Biology Teacher, 71, 465-472. https://doi.org/10.2307/20565359

Sampson, V., \& Walker, J. P. (2012). Argument-Driven Inquiry as a Way to Help Undergraduate Students Write to Learn by Learning to Write in Chemistry. International Journal of Science Education, 34, 1443-1485.

https://doi.org/10.1080/09500693.2012.667581

Sampson, V., Enderle, P. J., Grooms, J., \& Southerland, S. A. (2012). Using Laboratory Activities that Emphasize Argumentation and Argument to Help High School Students Learn How to Engage in Scientific Inquiry and Understand the Nature of Science. In Annual International Conference of the National Association for Research in Science Teaching (p. 57). Indianapolis, USA: NARST.

Sampson, V., Enderle, P., Gleim, L., Grooms, J., Hester, M., Southerland, S., \& Wilson, K. (2014). Argument-Driven Inquiry in Biology. Arlington, VA: NSTA Press. 
Sampson, V., Grooms, J., \& Enderle, P. (2011). New Instruments that Can Be Used by Researchers to Assess Three Different Aspects of Science Proficiency. In Fall Conference for the Society for Research on Educational Effectiveness (p. 19). Washington DC, USA: SREE.

https://www.sree.org/conferences/2011f/program/downloads/abstracts/321.pdf

Sampson, V., Grooms, J., \& Walker, J. P. (2009). Argument-Driven Inquiry: A Way to Promote Learning during Laboratory Activities. The Science Teacher, 76, 42-47.

Sampson, V., Grooms, J., \& Walker, J. P. (2011). Argument-Driven Inquiry as a Way to Help Students Learn How to Participate in Scientific Argumentation and Craft Written Arguments: An Exploratory Study. Science Education, 95, 217-257. https://doi.org/10.1002/sce.20421

Sandoval, W. A., \& Millwood, K. A. (2005). The Quality of Students' Use of Evidence in Written Scientific Explanations. Cognition and Instruction, 23, 23-55. https://doi.org/10.1207/s1532690xci2301_2

Sandoval, W. A., \& Reiser, B. J. (2004). Explanation-Driven Inquiry: Integrating Conceptual and Epistemic Scaffolds for Scientific Inquiry. Science Education, 88, 345-372. https://doi.org/10.1002/sce.10130

Simon, S., Erduran, S., \& Osborne, J. (2006). Learning to Teach Argumentation: Research and Development in the Science Classroom. International Journal of Science Education, 28, 235-260. https://doi.org/10.1080/09500690500336957

Sweller, J. (1988). Cognitive Load during Problem Solving: Effects on Learning. Cognitive Science, 12, 257-285. https://doi.org/10.1207/s15516709cog1202_4

Tekkaya, C. (2003). Remediating High School Students' Misconceptions Concerning Diffusion and Osmosis through Concept Mapping and Conceptual Change Text. Research in Science \& Technological Education, 21, 5-16. https://doi.org/10.1080/02635140308340

Vygotsky, L. S. (1978). Mind in Society. London: Harvard University Press.

Walker, J. P., Sampson, V., \& Zimmerman, C. O. (2011). Argument-Driven Inquiry: An Introduction to a New Instructional Model for Use in Undergraduate Chemistry Labs. Journal of Chemical Education, 88, 1048-1056. https://doi.org/10.1021/ed100622h

Watson, J. R., Swain, J. R. L., \& McRobbie, C. (2004). Research Report. International Journal of Science Education, 26, 25-45. https://doi.org/10.1080/0950069032000072764

Watters, D. J., \& Watters, J. J. (2007). Approaches to Learning by Students in the Biological Sciences: Implications for Teaching. International Journal of Science Education, 29, 19-43. https://doi.org/10.1080/09500690600621282

Wei, B., Chen, S., \& Chen, B. (2018). An Investigation of Sources of Science Teachers' Practical Knowledge of Teaching with Practical Work. International Journal of Science and Mathematics Education, 17, 723-738.

Zeidler, D. L. (1997). The Central Role of Fallacious Thinking in Science Education. Science Education, 81, 483-496. https://doi.org/10.1002/(SICI)1098-237X(199707)81:4<483::AID-SCE7>3.3.CO;2-R 